\title{
DESTRUCTIVE AND NON-DESTRUCTIVE PROPERTIES OF COBALT OXIDE SUBSTITUTED 1393 BIOACTIVE GLASS
}

\author{
S. K. Yadav, V. K. Vyas, P. Anand, M. R. Majhi and R. Pyare \\ Department of Ceramic Engineering, Indian Institute of Technology (Banaras Hindu University) \\ Varanasi -221005, India. \\ *E-mail: sandeep.rs.cer.2006@gmail.com
}

\begin{abstract}
This study is based on two types of tests; the first one is destructive and second is non- destructive. The mechanical properties of the sample were measured without destruction of the sample since the biomaterials were costly to prepare. In this study, cobalt oxide containing 1393 bioactive glass of general molar composition $\left[(53-\mathrm{X}) \mathrm{SiO}_{2}-\right.$ $6 \mathrm{Na}_{2} \mathrm{O}-20 \mathrm{CaO}-4 \mathrm{P}_{2} \mathrm{O}_{5}-12 \mathrm{~K}_{2} \mathrm{O}-5 \mathrm{MgO}+\mathrm{XCoO}$ )] (where $\mathrm{X}=0$ to $1.65 \mathrm{~mol} \%$ ) was melted in an alumina crucible $(99.7 \%)$ in an electric furnace at a temperature of $1400^{\circ} \mathrm{C}$ with air as furnace atmosphere. The structure of bioactive glass was evaluated using FTIR and XRD techniques. The destructive tests like micro hardness, compressive, flexural strengths and the non-destructive tests of elastic moduli were carried out. It was observed that substitution of cobalt oxide for silica in 1393 bioactive glass improved its density, compressive and flexural, micro hardness and elastic properties.
\end{abstract}

Key words: 1393 glass, cobalt oxide, mechanical properties, elastic modulus.

(c) RASĀYAN. All rights reserved

\section{INTRODUCTION}

Bioactive glasses (BGs) such as '45S5 Bioactive glass' (45 $\mathrm{SiO}_{2}, 24.5 \mathrm{CaO}, 24.5 \mathrm{Na}_{2} \mathrm{O}$, and $6 \mathrm{P}_{2} \mathrm{O}_{5}$ ) wt\% ${ }^{1}$ and '1393' (54.68 $\mathrm{SiO}_{2}, 5.98 \mathrm{Na}_{2} \mathrm{O}, 7.74 \mathrm{~K}_{2} \mathrm{O}, 7.74 \mathrm{MgO}, 22.11 \mathrm{CaO}$, and $1.79 \mathrm{P}_{2} \mathrm{O}_{5}$ ) mol\%2 ${ }^{2}$, compositions have been broadly used for bone tissue engineering applications. Apart from the aforementioned silicate glasses, borate and borosilicate glasses have now days found varying usage in biomedical and technological applications. ${ }^{3,5}$ On being exposed to biological conditions chemical degradation occurs in the BG leading to the formation of a hydroxyapatite (HA) layer which facilitates bonding between bones and tissues. ${ }^{6}$ BG's possess superior biocompatibility but owing to their weak mechanical strength and stability, avenues for their use as porous scaffolds were limited, Hence researchers' devised new strategies of ion doping for enhancing their biological performance. Among the prior mentioned BG's borate based glasses have a better controllable rate of degradation to form HA than silicate glasses ${ }^{7,9}$ which make them promising materials for future. Recent advances in the field of research in silicate based BG have to lead to newer compositions of BG by the incorporation of ions like cobalt, silver, zinc, magnesium, copper, strontium, fluoride, boron etc. in the silicate network. ${ }^{10-17}$ These ions can be slowly released in the human body in a controlled manner on scaffold degradation. These new glasses are highly beneficial as they help in the process of osteogenesis and angiogenesis and act as an anti-bacterial agent in chemical applications of engineered bone constructs. ${ }^{18-22}$ They are of importance as they can be used for the limited delivery of certain ions which control particular cell functions ${ }^{23}$, the carrier of homeostatic agents $^{24}$ and therapeutic drugs ${ }^{25}$, hyperthermia treatment of cancer $^{26}$ and also for soft tissue applications like nerve generation. ${ }^{27} 1393$ bioactive glasses tolerate strong bonding to hard and soft tissue and have been shown to endorse osteogenesis via the activation of several relevant genes. ${ }^{28}$ Cobalt ions are considered important in bone physiology ${ }^{29-32}$ as they induce hypoxia conditions and become stable hypoxia-inducible factor $^{33,34}$ which in turn, activates several pro-regenerative processes in the human body. ${ }^{35}$ HIF-1 activation leads to angiogenesis, stem cell differentiation, and fracture repair. ${ }^{36,37}$ Cobalt releasing bioactive glasses is thus called hypoxia-mimicking ${ }^{38}$ and has potential benefits in vivo. A higher concentration of Co can prove toxic ${ }^{34,39}$ and hence it needs to be released in a controlled manner in a 
physiological environment. In the present work, however, the mechanical properties of Co substituted 1393 bioactive glass have been studied to assess its suitability for various biological applications.

\section{Preparation of bioactive glass}

\section{EXPERIMENTAL}

Four batches having a concentration of raw materials were taken to prepare the glass samples. Normal melting and annealing techniques were used to prepare bioactive-glasses. For $\mathrm{SiO}_{2}$, quartz with fine grained was taken. Soda and lime were introduced in the form of their respective anhydrous carbonates $\left(\mathrm{Na}_{2} \mathrm{CO}_{3}\right.$ and $\left.\mathrm{CaCO}_{3}\right) . \mathrm{P}_{2} \mathrm{O}_{5}$ was added in the form of ammonium dihydrogen orthophosphate $\left(\mathrm{NH}_{4} \mathrm{H}_{2} \mathrm{PO}_{4}\right) . \mathrm{MgO}$ and $\mathrm{K}_{2} \mathrm{O}$ were also incorporated in the form of their respective carbonates $\left(\mathrm{MgCO}_{3}\right.$ and $\mathrm{K}_{2} \mathrm{CO}_{3}$ ). Cobalt Oxide was available as $\mathrm{CoO}$. The mol percent of the different bioactive glass samples composition is given in Table-1. These raw materials were mixed thoroughly for 30 minutes in an already cleaned mortar and pestle. Different batches were kept in alumina crucibles and placed in an electric furnace to melt at a temperature of $1400^{\circ} \mathrm{C}$ for 3 hours. This steady state was maintained for another hour after which the homogenized melts were poured onto an alumina moulds and transferred to a regulated electric furnace already at a temperature of $500^{\circ} \mathrm{C}$. The process of annealing was carried out for an hour after which the furnace was allowed to cool down to room temperature at a controlled rate of $10^{\circ} \mathrm{C}$ per minute. Glasses are annealed in order to remove any kind of internal stresses which developed during the formation process to prevent them from cracking on the application of mechanical or thermal shocks.

Table-1: Composition of Bioactive Glass (Mol \%)

\begin{tabular}{c|c|c|c|c|c|c|c}
\hline & $\mathrm{SiO}_{2}$ & $\mathrm{Na}_{2} \mathrm{O}$ & $\mathrm{CaO}$ & $\mathrm{P}_{2} \mathrm{O}_{5}$ & $\mathrm{CoO}$ & $\mathrm{K}_{2} \mathrm{O}$ & $\mathrm{MgO}$ \\
\hline 1393 & 54.68 & 5.98 & 22.11 & 1.79 & 0 & 7.74 & 7.74 \\
\hline $\mathrm{Co}-1$ & 54.22 & 5.99 & 22.13 & 1.75 & 0.41 & 7.75 & 7.75 \\
\hline $\mathrm{Co}-2$ & 53.78 & 5.99 & 22.15 & 1.74 & 0.84 & 7.75 & 7.75 \\
\hline $\mathrm{Co}-3$ & 53.29 & 6.02 & 22.18 & 1.75 & 1.24 & 7.76 & 7.76 \\
\hline $\mathrm{Co}-4$ & 52.85 & 6.02 & 22.19 & 1.75 & 1.65 & 7.77 & 7.77 \\
\hline
\end{tabular}

\section{X-ray diffraction measurements}

The bioactive glass samples were ground to powder form having a grain size of $75 \mu \mathrm{m}$ for X-ray diffraction analysis. XRD is done in order to distinguish and identify the crystalline phases present in the glass which itself is amorphous in nature. A RIGAKU-Miniflex II difractometer adopted $\mathrm{Cu}-\mathrm{K} \alpha$ radiation $\left(\lambda=1.5405 \AA\right.$ ) having a tube voltage of $40 \mathrm{kV}$ and current of $35 \mathrm{~mA}$ was used in the $2 \Theta$ range between $20^{\circ}$ and $80^{\circ}$. The step size was set to $0.02^{\circ}$ and the measuring speed was $1^{\circ}$ per minute. JCPDS data cards were used as a reference for identifying the peaks in the graph.

\section{Structural analysis using FTIR spectrometry}

FTIR spectrometry is carried out in order to identify the functional groups present in the bioactive glasses. For this the powdered glass samples were mixed with $\mathrm{KBr}$ in the ratio of 1:100 respectively and were put inside an evocable die to form homogeneous discs by applying a load of $10 \mathrm{MPa}$. As $\mathrm{KBr}$ is prone to moisture attack, the discs were immediately subjected to an IR spectrometer (VARIAN Scimitar 1000, USA) for measuring the absorption spectra. The analysis was done at room temperature within the frequency range of $4000-400 \mathrm{~cm}^{-1}$.

\section{Density measurement}

The densities of all samples were measured at room temperature using a digital balance (Satorius, ModelBP221S, USA) which has an accuracy of $\pm 0.0001 \mathrm{gm}$. Water was used as an immersion fluid. Density was determined by Archimedes principle using the following formula:

Density $=\left[\mathrm{W}_{\mathrm{a}} /\left(\mathrm{W}_{\mathrm{a}}-\mathrm{W}_{\mathrm{w}}\right)\right]$ x 0.988

Where, ' $\mathrm{W}_{\mathrm{a}}$, is the weight in air, ' $\mathrm{W}_{\mathrm{w}}$ ' is the weight in water and density of water is 0.988. 


\section{Measurement of Mechanical Properties \\ Flexural Strength}

The bioactive glass samples were cast in cubical shape and were ground and polished to get the desired size of $1 \mathrm{~cm} \times 1 \mathrm{~cm} \times 1 \mathrm{~cm}$. These samples were subjected to three points bending test at room temperature using an Instron Universal Testing Machine (AGS 10kND, SHIMADZU) whose cross- head speed was $0.5 \mathrm{~mm} / \mathrm{min}$ bearing a full-scale load of $2500 \mathrm{~kg}$. The calculation of flexural strength was calculated using the formula:

$$
\mathrm{F}=\left(3 \mathrm{P}_{\mathrm{f}} \mathrm{L}\right) /\left(2 b h^{2}\right)
$$

Where ' $\mathrm{P}_{\mathrm{f}}$ ' is the load and ' $\mathrm{L}$ ', ' $\mathrm{b}$ ', ' $\mathrm{h}$ ' are the length, breadth, and height of the glass samples respectively.

\section{Compressive Strength}

For measuring compressive strength of the bioactive glass samples the Instron Universal Testing Machine was used having a cross-speed of $0.05 \mathrm{~cm} / \mathrm{min}$ and a full-scale load of $2500 \mathrm{~kg}$. The samples were cut into the desired size of $2 \mathrm{~cm} \times 2 \mathrm{~cm} \times 1 \mathrm{~cm}$ according to ASTM standard D3171 and the test was conducted at room temperature.

\section{Hardness}

The hardness of specimens having a size of $1 \mathrm{~cm} \times 1 \mathrm{~cm} \times 1 \mathrm{~cm}$ according was measured to ASTM standard C730-98 using the Hardness Testing Machine. Indentations were made on the samples with loads lying within the range of $30 \mathrm{mN}-2000 \mathrm{mN}$ which were applied at a velocity of $0.1 \mathrm{~cm} / \mathrm{sec}$. The formula for calculation of micro hardness $(\mathrm{GPa})$ is given as below:

$$
\mathrm{H}=1.854 \times\left(\mathrm{P} / \mathrm{d}^{2}\right)
$$

Where ' $\mathrm{P}$ ' is the load and ' $\mathrm{d}$ ' is the diagonal of the indentation.

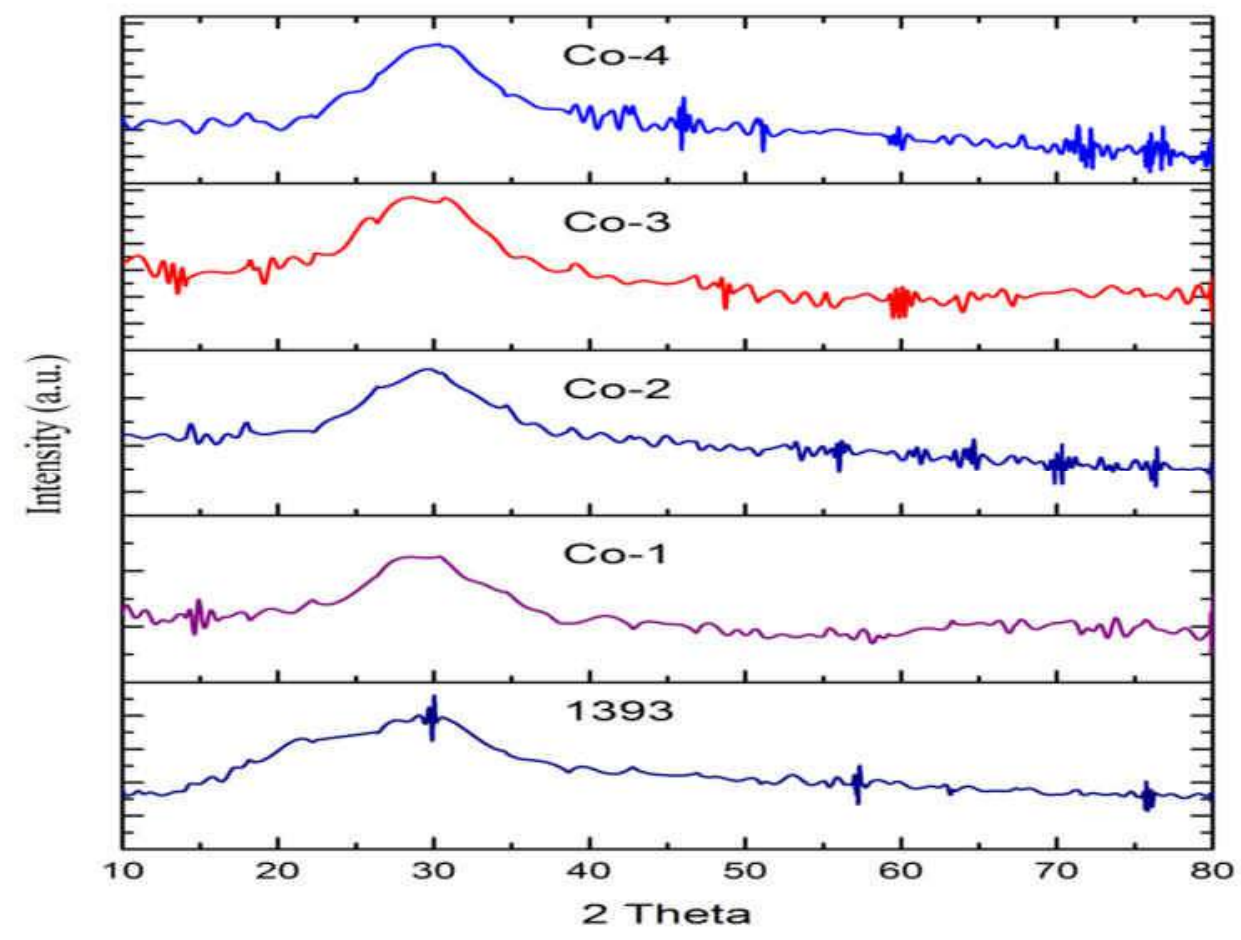

\section{Elastic Properties}

Fig.1- XRD base and substituted bioactive glass

The 1393 and Cobalt doped glass samples were cut and polished into cubic pieces and placed inside the instrument Olympus (M-45, USA) for measuring the ultrasonic wave velocities. Sonfech shear gel and 
Couplant glycerin were used for measuring the shear and longitudinal wave velocities respectively. Various formulae involving these velocities and density values were used for the calculation of Poisson's Ratio, Young's, Shear and Bulk Modulus of elasticity.

\section{X-Ray analysis of bioactive glasses}

\section{RESULTS AND DISCUSSION}

The XRD patterns for an un-doped and Co doped 1393 bioactive glass samples are shown in Fig. 1. The results obtained are in good agreement with the fact that glass is an amorphous nature and hence the figure is devoid of peaks which indicate the absence of any crystalline phase. The hump for $2 \Theta$ values between $25^{\circ}$ and $35^{\circ}$ intensifies with the addition of cobalt oxide and is the only change visible in the different graphs. It also shows that cobalt oxide is totally dissolved in the glass matrix.

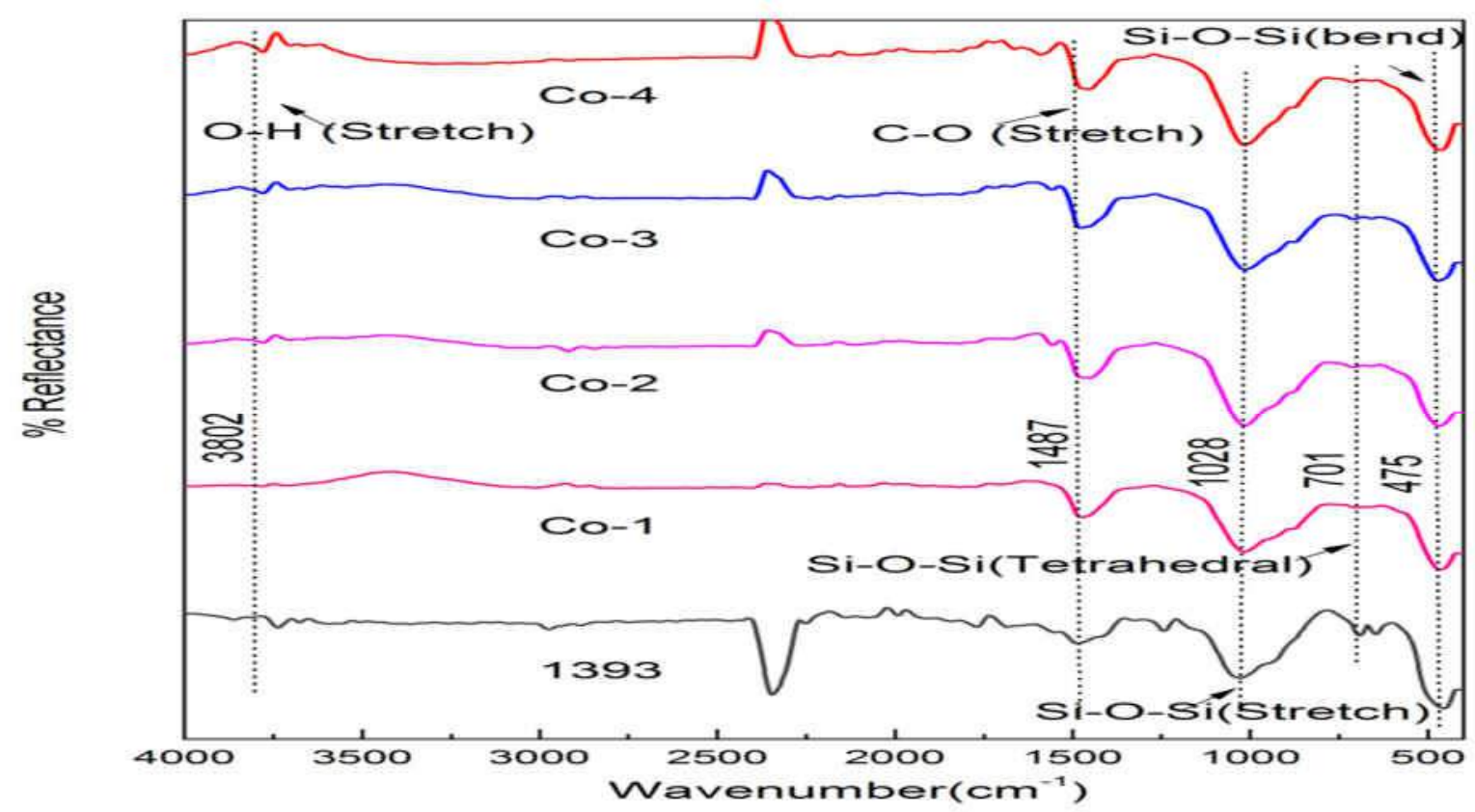

Fig.-2: FTIR base and substituted bioactive glass

\section{FTIR Spectra of Bioactive glass}

Figure-2 shows the FTIR Reflection spectra of base 1393 bioactive glass and Co substituted 1393 bioactive glass. The presence of silicate network is confirmed from the obtained spectra bands due to $\mathrm{SiO}_{2}$ being the major constituent. Peaks can be seen at 475, 701, 1028, 1487 and $3802 \mathrm{~cm}^{-1}$. The peak at $475 \mathrm{~cm}^{-1}$ can be connected with Si-O-Si symmetric bending mode and the one at $701 \mathrm{~cm}^{-1}$ corresponds to a symmetric stretch of non-bridging oxygen atoms. The main band at $1028 \mathrm{~cm}^{-1}$ can be attributed to Si-O$\mathrm{Si}$ stretching mode. The small band at $1487 \mathrm{~cm}^{-1}$ can be assigned to the $\mathrm{C}-\mathrm{O}$ vibration mode. Finally, the small and broad band at $3802 \mathrm{~cm}^{-1}$ can be associated with the hydroxyl group (-OH) which indicates the presence of adsorbed water molecules. There is no any noticeable change in the IR spectra bands in the cobalt oxide substituted 1393 bioactive glass.

\section{Density Measurements and Mechanical Properties of doped and un-doped 1393 bioactive glass}

The variation in density measurements calculated using Archimedes' principle is depicted in Fig.-3 which clearly indicated that the addition of cobalt oxide makes the glass denser and therefore the density gradually increases from 2.88 to $2.97 \mathrm{~g} / \mathrm{cm}^{3}$. This increase can be ascribed due to partial replacement of lighter element $\mathrm{SiO}_{2}$ having density $2.65 \mathrm{~g} . \mathrm{cm}^{-3}$ with heavier cobalt oxide having density $6.11 \mathrm{~g} . \mathrm{cm}^{-3}$. 
The flexural strength (Fig.-4) of 1393, Co-1, Co-2, Co-3, Co-4 bioactive glass was measured as 44.46, 57.24, 58.41, 62.49, 66.55 MPa and compressive strength (Fig.-5) as 69.82, 78.63, 81.35, 79.15, 84.13 MPa respectively. Micro Hardness (Fig.-6) values on calculation came out to be 5.45, 5.58, 5.61, 5.87, 6.09 GPa for the aforementioned glasses respectively. All of them show an increasing trend on subsequent addition of cobalt oxide. Cobalt acts as a network intermediate when added in quantities less than $2 \mathrm{wt} \%$ and as a modifier when its concentration lies between 2 and $4 \mathrm{wt} \%$ [36]. As in the present study, there has been a gradual addition of $0-1.65 \mathrm{~mol} \%$ of $\mathrm{Co}^{2+}$ ions it acted as an intermediate and made the glass structure more compact. This justifies the changing trend in the mechanical properties.

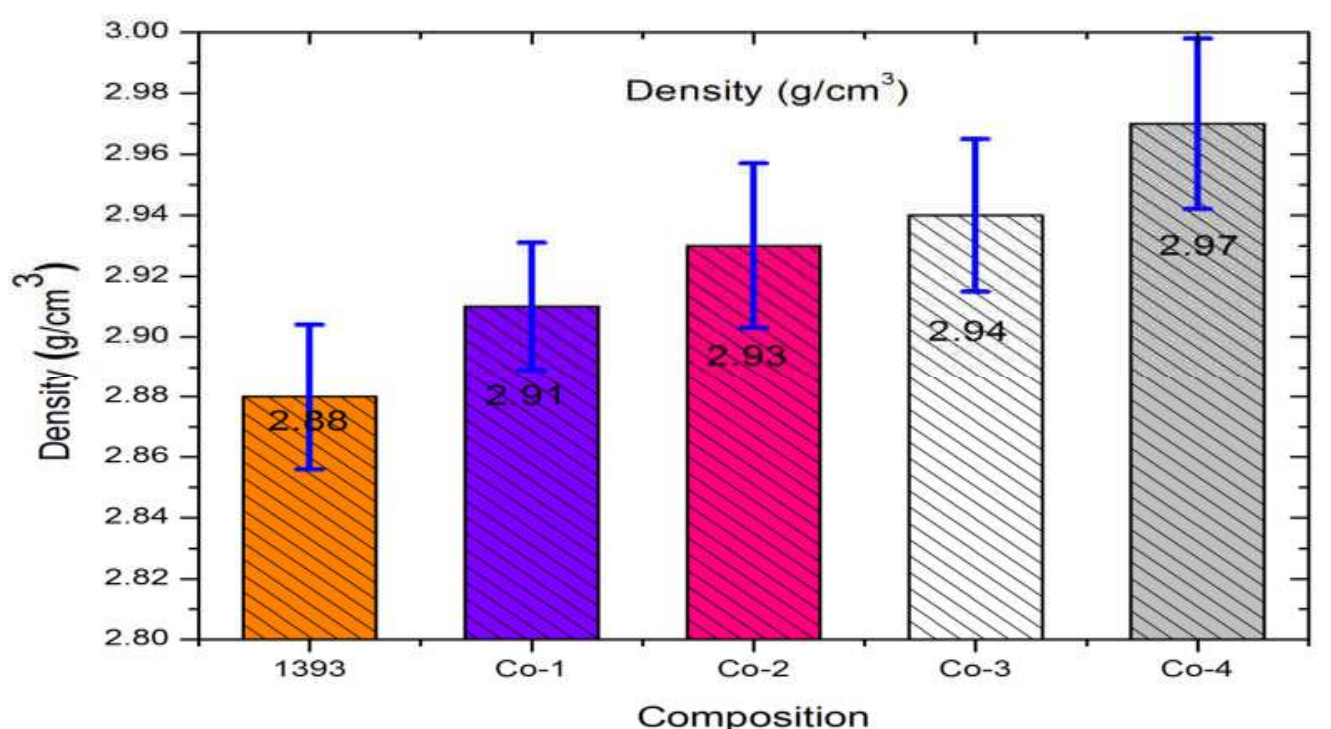

Fig.-3: Density of base and substituted bioactive glass

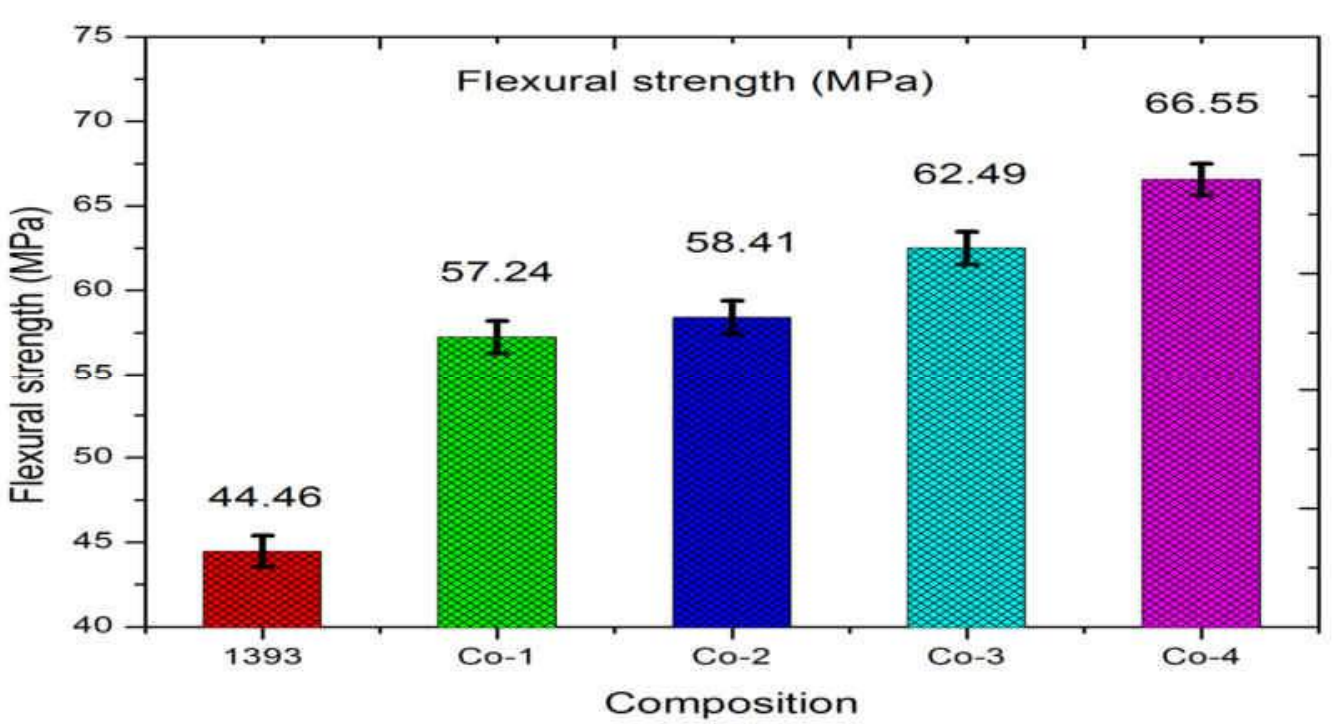

\section{Elastic Properties}

Fig.-4: Flexural strength of base and substituted bioactive glass

The elastic properties namely Poisson's Ratio, Young's, Shear and Bulk modulus of glasses were calculated using the longitudinal and shear ultrasonic wave velocities. These values were having graphically represented in Figures- 7 to 10. There is an increase in values of Young's, shear and bulk modulus with an increase in $\mathrm{Co}^{2+}$ concentration whereas a slightly decreasing trend in values is observed for Poisson's ratio. The increase in elastic modulus values has been earlier reported by Gaafar and 
Kannapan ${ }^{40,41}$ which was ascribed to the increase in connectivity in the glass network. However, the slight reduction in Poisson's ratio could have been due to change in the type of bonding in the glass structure on the addition of cobalt oxide ${ }^{42}$.

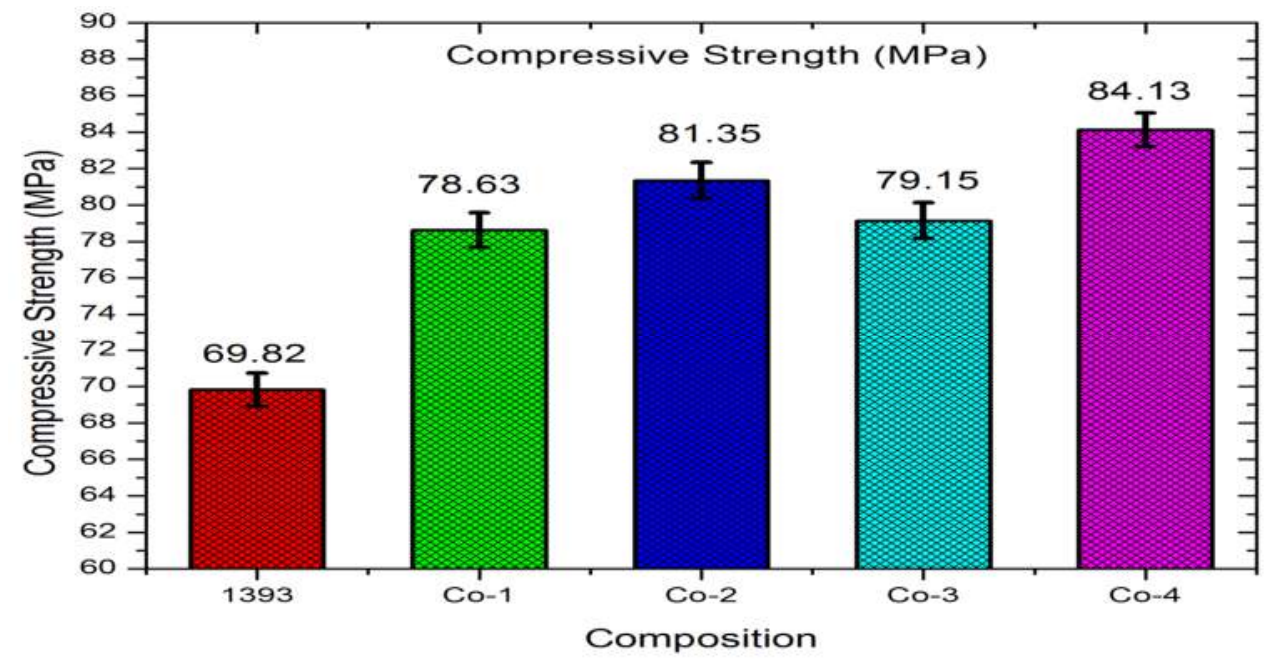

Fig.-5: Compressive strength of base and substituted bioactive glass

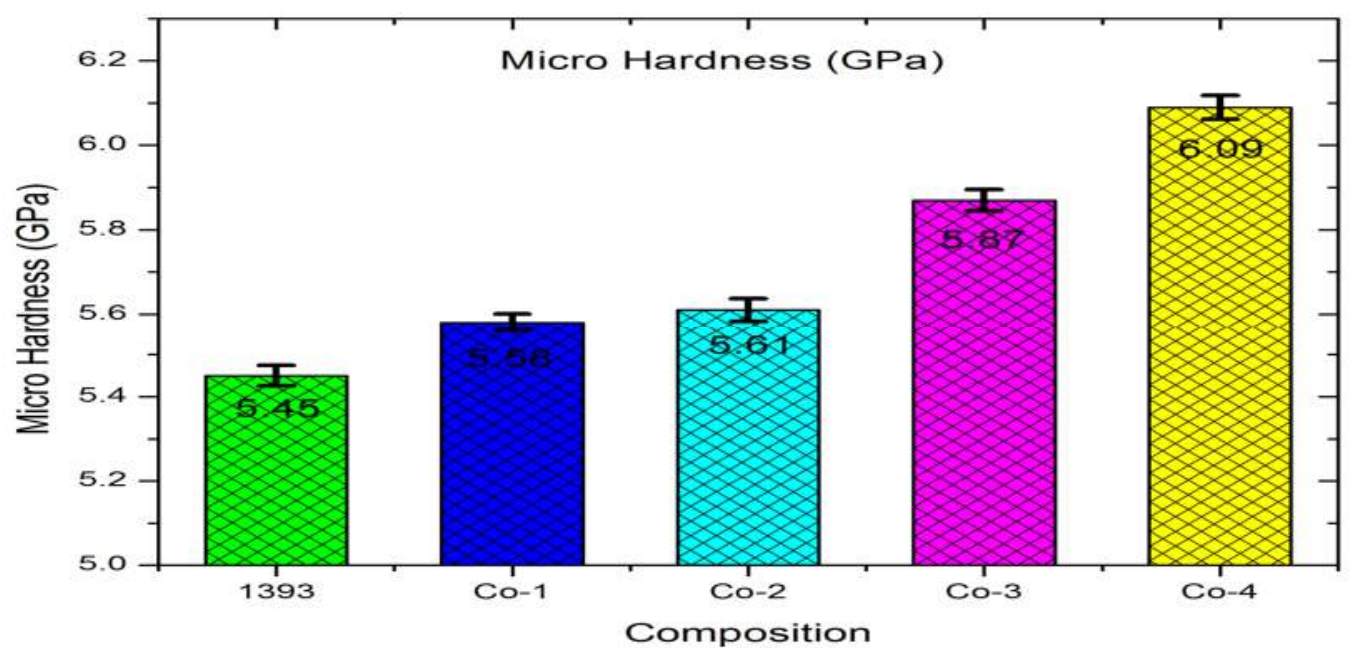

Fig.-6: Micro Hardness of base and substituted bioactive glass

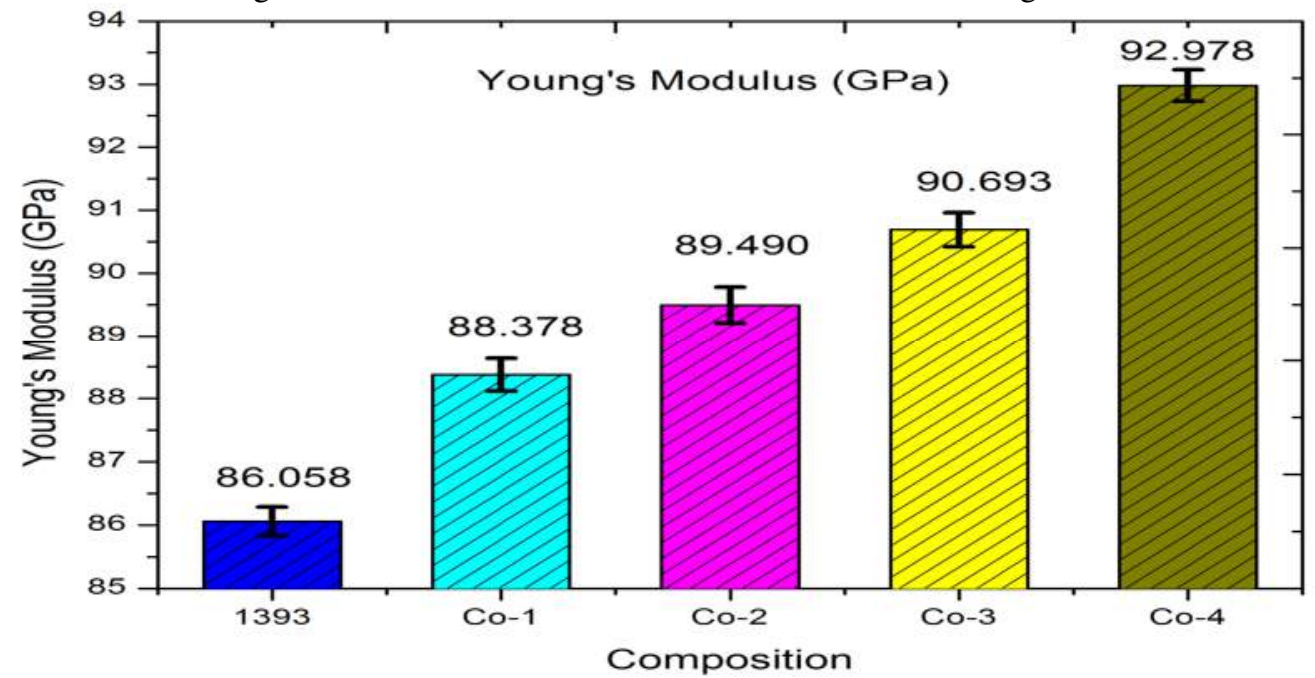

Fig.-7: Young's Modulus of base and substituted bioactive glass 


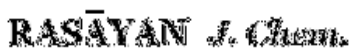

Vol. 10 | No. 3 |935 - 943 | July - September | 2017

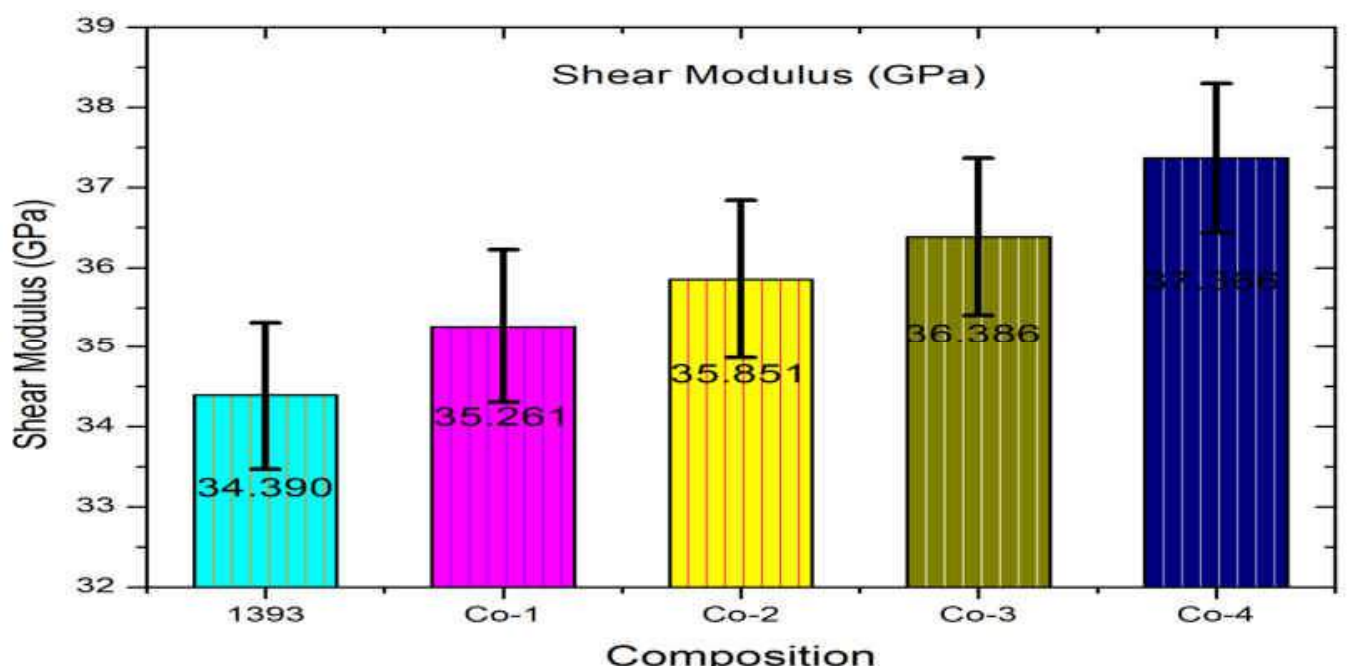

Fig.-8: Shear Modulus of base and substituted bioactive glass

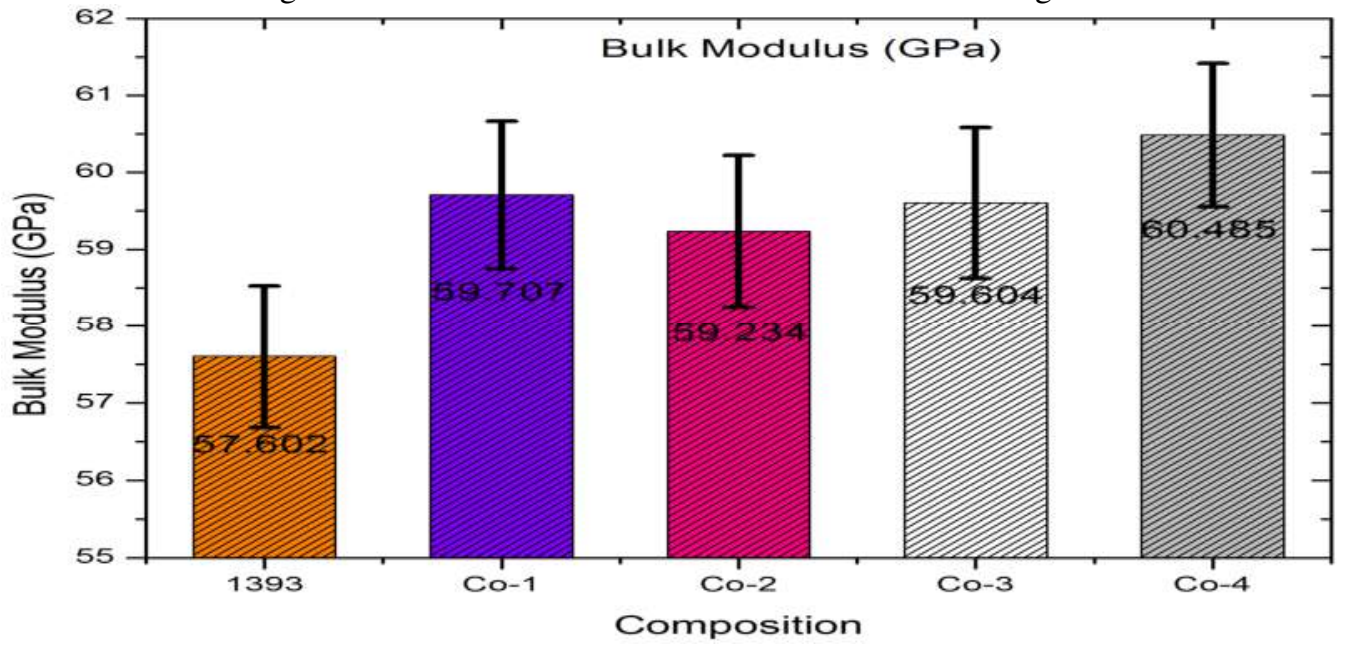

Fig.-9: Bulk Modulus of base and substituted bioactive glass

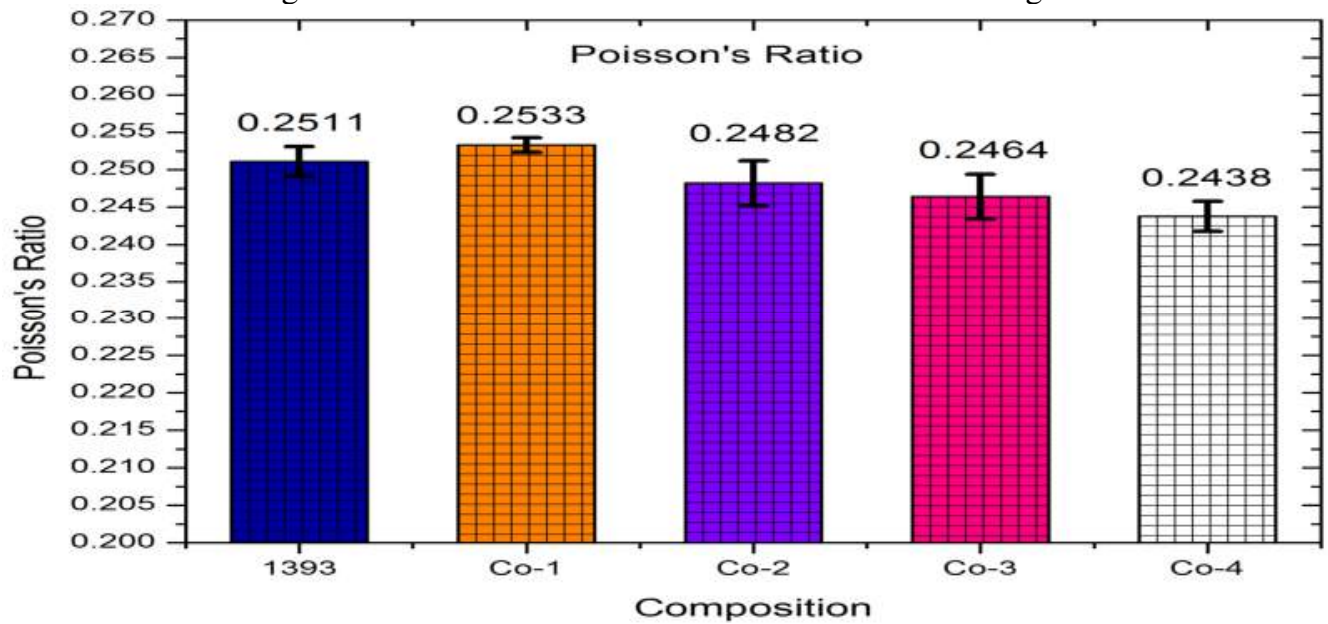

Fig.-10: Poisson's Ratio of base and substituted bioactive glass

\section{CONCLUSION}

In the present investigation, various types of properties were carried out on $1393, \mathrm{Co}-1, \mathrm{Co}-2, \mathrm{Co}-3$, Co-4 substituted bioactive glass samples. Firstly, the XRD analysis confirmed the amorphous nature of glass 
and FTIR result showed the presence of silicate network in the glass structure. The study of mechanical properties namely bending and compressive strength and hardness and elastic properties namely Young's, bulk and shear moduli show an upward trend of increasing the concentration of $\mathrm{CoO}$ in the bioactive glass. However, the values for Poisson's ratio reduce slightly on $\mathrm{Co}^{2+}$ addition. On the one hand as the doped bioactive glass emerges to be mechanically stronger than the base glass but on the other hand, it is structurally weaker in due to replacement of stronger $\mathrm{Si}-\mathrm{O}-\mathrm{Si}$ bonds with $\mathrm{Co}-\mathrm{O}-\mathrm{Si}$ bonds. Therefore on summarizing the results obtained from this investigation, it can be concluded that cobalt oxide substituted 1393 bioactive glass can be used in biomedical applications as a potential biomaterial.

\section{ACKNOWLEDGMENT}

The authors gratefully acknowledge the HOD Department of Ceramic Engineering, Indian Institute of Technology (Banaras Hindu University) Varanasi -221005, India the honorable Director of Indian Institute of Technology (Banaras Hindu University) Varanasi, India for providing necessary facilities for the present work.

\section{REFERENCES}

1. L. L. Hench, J. Am. Ceram.Soc., 74 (7), 1487(1991).

2. M. N Rahaman. D. E Day, B. S Bal, Q. Fu, S. B Jung, L. F. Bonewald and A. P Tomsia, Acta Biomater., 7 (6), 2355(2011).

3. Y. Yun, P. Bray, J. Non-Cryst. Solids, 27 (3) ,363(1978)

4. Q.Z. Chen, I.D. Thompson and A.R. Boccaccini, Biomaterials ,27 (11) 2414(2006).

5. T. Kokubo, H. Takadama, Biomaterials, 27 (15), 2907(2006).

6. W. Cao and L.L. Hench, Bioactive materials, Ceram. Int. ,22 (6) 493(1996).

7. H. Fu, Q. Fu, N. Zhou,W. Huang, M.N. Rahaman, D.Wang and X. Liu, Mater. Sci. Eng., C ,29 (7) 2275(2009).

8. M. Cerruti, Phys. Eng. Sci., 370, 1281(2012).

9. T. Furukawa and W.B. White, Phys. Chem. Glasses, 20 (4), 69(1979).

10. A.R. Boccaccini, ACS Appl. Mater. Interfaces, 6, 2865(2014).

11. M. Bellantone, H. D. Williams, and L. L. Hench, Antimicrob. Agents Chemother., 46, 1940(2002).

12. S. Haimi, et al., Acta Biomater., 5 ,3122(2009).

13. M. Diba, F. Tapia, A. R. Boccaccini, and L. A. Strobel, Int. J. Appl.Glass Sci, 3 ,221(2012).

14. H.Wang et al., Materials Science and Engineering C , 58, 194(2016).

15. J. Lao, J. M. Nedelec, and E. Jallot, J. Mater. Chem., 19, 2940(2009).

16. E. Gentleman, et al., Acta Biomater., 9 ,5771(2013).

17. X. Liu, et al., J. Mater. Sci. Mater. Med., 20, 1237(2009).

18. H. Pan, X. Zhao, X. Zhang, K. Zhang, L. Li, Z. Li, W. Lam, W. Lu, D. Wang and W. Huang, J. $R$. Soc. Interface ,7 (48), 1025(2010).

19. D. Clupper and L. Hench, J. Mater. Sci. Mater. Med., 12 (10-12), 917(2001).

20. C.Wu,W. Fan, Y. Zhu,M. Gelinsky, J. Chang, G. Cuniberti, V. Albrecht, T. Friis and Y. Xiao, Acta Biomater., 7 (10), 3563(2011).

21. H. Wang, S. Zhao, J. Zhou, Y. Shen, W. Huang, C. Zhang, M.N. Rahaman and D. Wang, J. Mater. Chem. $B, 2$ (48), 8547(2014).

22. W. Hui, W. Deping, H. Wenhai, L. Shihua, C. Xu, S. Youqu, J. Fei and L. Le, Rare Metal Mater. Eng. , 43, 54(2014).

23. A. Hoppe, N. S. Geuldal, and A. R. Boccaccini, Biomaterials, 32 2757(2011).

24. T. A. Ostomel, Q. Shi, C. K. Tsung, H. Liang, and G. D. Stucky, Small, 2(11) 1261(2006).

25. J. Hum and A. R. Boccaccini, J. Mater. Sci. Mater. Med., 23, 2317(2012).

26. O. Bretcanu, S. Spriano, C. B. Vitale, and E. Verne, J. Mater. Sci., 41, 1029(2006).

27. X. F. Zhang, H. O'Shea, S. Kehoe, and D. Boyd, J. Mech. Behav. Biomed. Mater., 4, 1266(2011).

28. L. L Hench, J. Eur. Ceram. Soc., 29 (7), 1257(2009).

29. R. Buttyan, P. Chichester, B. Stisser, S. Matsumoto, M.A. Ghafar and R.M. Levin, J. Urol. ,169(6), 2402(2003). 
30. S. Patntirapong, P. Habibovic and P.V. Hauschka, Biomaterials ,30(4), 548(2009).

31. K. Peters, H. Schmidt, E.R. Unger and C. James, Application to Studies of Biocompatibility, Vol. 23 Elsevier, Oxford, ROYAUME-UNI, (2002).

32. T. Tanaka, I. Kojima, T. Ohse, J.R. Ingelfinger, S. Adler, T. Fujita and M. Nangaku, Lab. Investig., 85 (10), 1292(2005).

33. G. Chachami, G. Simos, A. Hatziefthimiou, S. Bonanou, P.-A. Molyvdas and E. Paraskeva, Am. J. Respir. Cell Mol. Biol. ,31 (5), 544(2004).

34. K. Peters, H. Schmidt, R. Unger, G. Kamp, F. Pröls, B. Berger and C.J. Kirkpatrick, Mol. Cell. Biochem., 270 (1-2), 157(2005).

35. G.L. Semenza, Life with oxygen, Science, 318 (5847), 62(2007).

36. M.M. Azevedo, G. Jell, M.D. O'Donnell, R.V. Law, R.G. Hill and M.M. Stevens, J. Mater. Chem., 20 (40), 8854(2010).

37. P.J. Emans, F. Spaapen, D.A.M. Surtel, K.M. Reilly, A. Cremers, L.W. van Rhijn and R. Kuijer, Bone ,40 (2), 409(2007).

38. M. Azevedo, G. Jell, R. Hill and M.M. Stevens, Eur. Cell. Mater. 18 (Suppl. 2), 45 (2009).

39. C. Fleury, A. Petit, F. Mwale, J. Antoniou, D.J. Zukor, M. Tabrizian and O.L. Huk, Biomaterials ,27 (18), 3351(2006)

40. M. S. Gaafar, S. Y. Marzouk, H. A. Zayed, L. I. Soliman and A. H. Serag El-Deen, Curr. Appl. Phys., 13, 152(2013).

41. A. N. Kannappan, S. Thirumaran and R. Palani, ARPN J. Eng. Appl. Sci., 4, 27(2009).

42. M. S. Gaafar, F. H. ElBatal, M. ElGazery and S. A. Mansour, Acta Phys. Polonica A, 115, 671(2009).

[RJC-1808/2017] 